\title{
Energy Efficiency of a Wooden House
}

\author{
Anca Constantin
}

\begin{abstract}
An exemplary construction project developed in a commune close to Constanta, Romania, aims to build wooden houses for families with low income. The study focuses on their energy performance, aiming to determine simple technical solutions for the improvement of energy efficiency. The original house is a duplex ground floor building. The energy assessment was performed in accordance with the Romanian methodology for the original house, for the reference one and for a variant of the original house whose ground floor is insulated. The study showed that appropriate insulation of the ground floor which covers $30 \%$ of the thermal envelope area results in a heating energy saving of $17 \%$. Furthermore, the original horizontal duplex was compared to its similar vertical version (ground floor and one storey) which is more compact, at the same heated volume and the same heated area. The reference vertical version saves $3 \%$ of heating energy.
\end{abstract}

Keywords: energy performance; heating energy; heat transmission; thermal resistance; wooden house

\section{INTRODUCTION}

The state of the art in the field of the energy performance of buildings brings in front of specialists the concept of smart sustainable buildings, encouraging an interweaved approach based on interior comfort, energy consumption and environment preservation. Besides these design principles, the Active House approach to buildings outlines the importance of the feedback from users [1]. Focusing on the inhabitants' wellbeing, the promoters of the Active House approach say that "today we have the technology and competences needed to build energy efficient buildings that positively affect our personal health" [1]. Unfortunately, the investment cost behind such a smart and energy efficient house is not affordable for the majority of people. Therefore, the engineers have to search for a cost-effective variant to build or rehabilitate a house, i.e. they have to obtain maximal possible energy efficiency and human comfort with minimal costs. This is the case of a generous project undertaken by the town hall of Cumpăna, in partnership with the Habitat for Humanity Cumpăna, that aims to build duplex ground floor houses for families in need [2]. Cumpăna is a commune close to Constanta, in the Dobrogea region, Romania.

Taking into consideration a low budget and a short building time, the houses have timber structure. They are sustainable, comfortable and affordable buildings. They are duplex ground floor houses and each includes two similar apartments. Wood-based panels are easy to work with and prefabricated elements are involved. Despite the fact that its compressive strength is similar to that of concrete, timber is used for low-rise structures. An important advantage, from the viewpoint of energy consumption, is that wood results in less thermal bridging than concrete or other construction materials. Moreover, the heat insulation performance of a $150 \mathrm{~mm}$ thick wooden wall is similar to that of a $610 \mathrm{~mm}$ thick brick wall [3]. However, wooden houses without thermal storage mass are more likely to overheat than brick houses [4]. Päätalo reconsiders a structure used in Middle Europe, namely an insulated double log wall, which provides a thermal transmission coefficient of $0.128 \mathrm{~W} \cdot \mathrm{m}^{-2} \cdot{ }^{\circ} \mathrm{C}^{-1}$, for a $40 \mathrm{~cm}$ thickness made of two spruce log layers and with insulation between them [5].

In regions where there is a lack of wood, the wood-based panels are a cheap building material alternative. The thermal insulation properties of an oriented strand board and plywood-faced sandwich panels manufactured as woodbased structural insulation materials for walls and floors are very much appreciated. The thermal conductivity value of $0.12 \mathrm{~W} \cdot \mathrm{m}^{-1 .}{ }^{\circ} \mathrm{C}^{-1}$ for an oriented strand board with the specific heat of $1500 \mathrm{~J} \cdot \mathrm{kg}^{-1} \cdot{ }^{\circ} \mathrm{C}^{-1}$, at a temperature of $20.3^{\circ} \mathrm{C}$ was reported by [6]. Later studies, such as [7], showed that the temperature influence on thermal conductivity manifested differently in transverse or in-plane direction for many types of panels. Less influence was reported in the case of the oriented strand board, for which the thermal conductivity was found to be of $0.275 \mathrm{~W} \cdot \mathrm{m}^{-1} \cdot{ }^{\circ} \mathrm{C}^{-1}$ for inplane direction and of $0.215 \mathrm{~W} \cdot \mathrm{m}^{-1 .}{ }^{\circ} \mathrm{C}^{-1}$ for transverse direction, at a specific heat of $1552 \mathrm{~J} \cdot \mathrm{kg}^{-1} \cdot{ }^{\circ} \mathrm{C}^{-1}[7]$.

Zehn [8] experimentally analysed the energy performance of a timber building placed in a cold region of China, and mentioned the rapid cooling of an uninhabited house as an accidental power failure occurs. They estimated the energy consumption of $24.61 \mathrm{~W} \cdot \mathrm{m}^{-2} \cdot$ year $^{-1}$ for heating, as the wall thermal coefficient was $3.936{ }^{\circ} \mathrm{C} \cdot \mathrm{m}^{2} \cdot \mathrm{W}^{-1}$ at an indoor temperature of $20^{\circ} \mathrm{C}$ [8]. The external temperature was not reported.

Moreover, the primary energy input in building materials is evaluated to be about $60-80 \%$ higher for concrete frames versus the wooden ones [9]. This assessment regarding the emissions was later confirmed by [10].

A high energy performance house can be achieved at a high investment cost, but the payback is usually rapid enough. When it comes to low-budget houses, not only low investment cost is important, but any effort to design the building as an energy efficient one must be taken into consideration.

The aim of our study is the energy performance assessment of a wooden house placed in a sunny and warm region of Romania, close to the Black Sea Coast. The study determines the difference in the heating energy consumption, primary energy and carbon dioxide footprint between the real 
house and the reference one and it also identifies the possibility of the energy efficiency improvement of the real house, taking into account a more compact version.

\section{DESCRIPTION AND EMPLACEMENT OF THE WOODEN HOUSE}

The new neighbourhood of Habitat houses is placed in the western part of Cumpăna. The first duplex houses have already been built, as it may be seen in Fig. 1 .

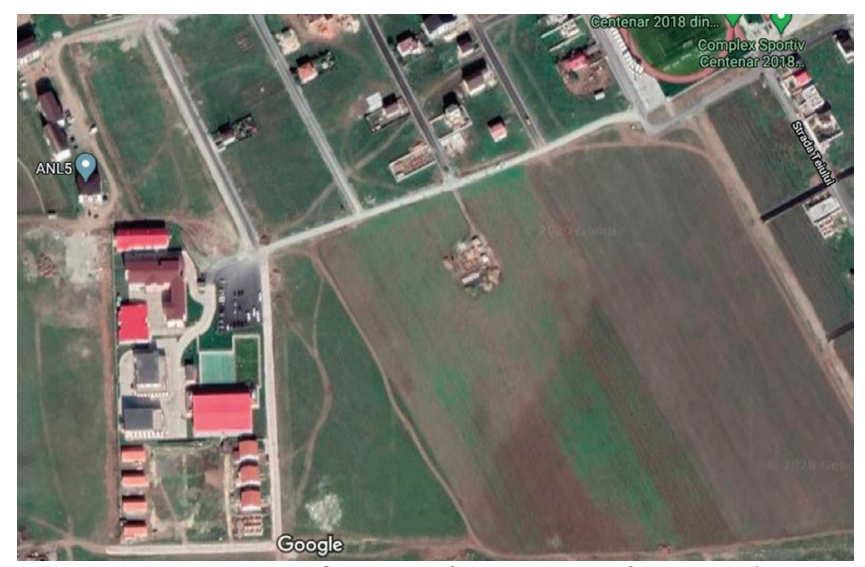

Figure 1 Habitat houses in Cumpăna, left bottom corner of the picture (source Google Maps)

Romania has five climatic regions. Cumpăna is situated on the Black Sea Coast, which is included in the first climatic region, characterized by a climate warmer than that in other regions. The yearly reduced temperature is $12.1{ }^{\circ} \mathrm{C}$ and the winter temperature for calculation is $-12^{\circ} \mathrm{C}$. The solar radiation has high intensity.

The depth of the groundwater was 10-12 m or even more. As the Black Sea-Danube canal was built close to this commune, the depth changed, in some areas the water rose to 5-6 $\mathrm{m}$ and in others it dropped to $15-16 \mathrm{~m}$. Precipitations are low in this dry climate area.

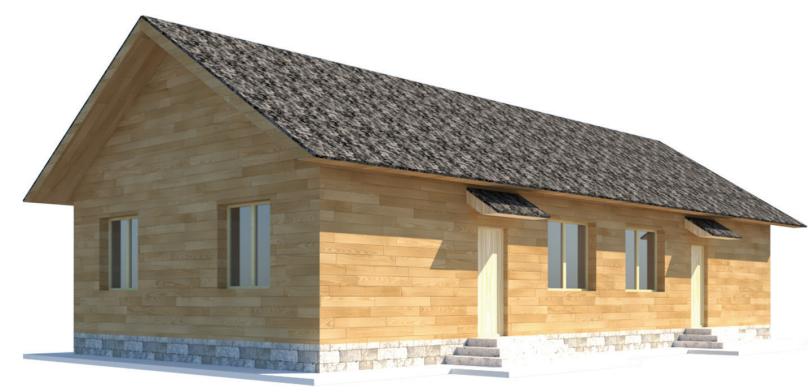

Figure 2 Duplex house (the original horizontal duplex)

The houses are light timber structured with simple architecture, as in Fig. 2. They have two ground floor apartments and an attic. The foundations are continuous with simple concrete blocks and reinforced concrete elevations under the walls. The perimeter walls are $25 \mathrm{~cm}$ thick and the interior partitions have a thickness of $20 \mathrm{~cm}$. They are made of wood-based panels with mineral wool in-between.
Each apartment is composed of a living room, two bedrooms, a kitchen and a bathroom. The duplex covers a rectangular area, $17 \times 8 \mathrm{~m}$, as it may be seen in Fig. 3 .

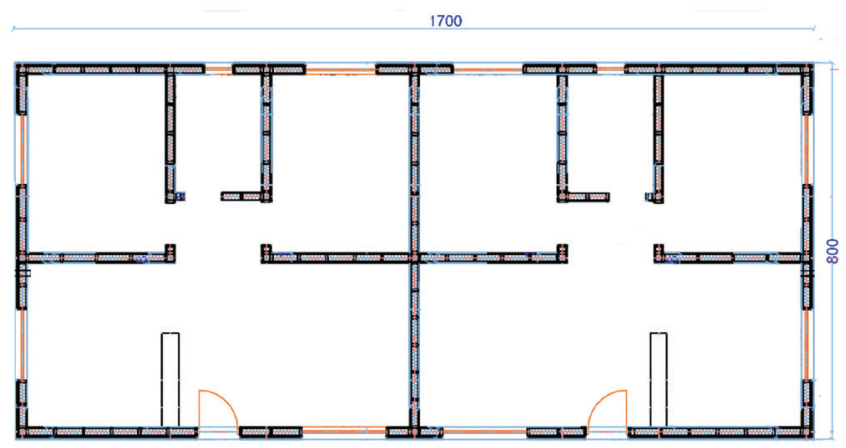

Figure 3 Ground floor layout

The walls have a good protection from fire and their thermal insulation is given through a thick layer of mineral wool.

\section{METHODOLOGY OF THE ENERGY PERFORMANCE ASSESSMENT}

\subsection{Theoretical Considerations}

The thermal energy transfer through a wall, which separates an indoor fluid medium of temperature $\theta_{\mathrm{i}}$ from an outdoor fluid of temperature $\theta_{\mathrm{e}}$, depends on the thermal resistance of the wall, $\mathrm{R}\left({ }^{\circ} \mathrm{C} \cdot \mathrm{m}^{2} \cdot \mathrm{W}^{-1}\right)$. The thermal resistance is:

$R=\frac{1}{\alpha_{\mathrm{e}}}+\frac{\delta}{\lambda}+\frac{1}{\alpha_{\mathrm{i}}^{\prime}}$,

where: $\mathrm{i}$ - index for indoor parameters; $\mathrm{e}$ - index for outdoor parameters; $\alpha_{\mathrm{i}}, \alpha_{\mathrm{e}}$ - coefficients of the thermal convection of the internal and external surface of the wall, $\left(\mathrm{W} \cdot \mathrm{m}^{-2} \cdot{ }^{\circ} \mathrm{C}^{-1}\right) ; \delta$ - thickness, (m); $\lambda$ - coefficient of thermal conductivity,

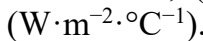

Considering the stationary, the one-dimensional heat transfer through an infinite, homogenous one-layer wall, the thermal flux that passes through a normal area $A$, may be written as:

$\dot{Q}=\frac{A}{R}\left(\theta_{\mathrm{i}}-\theta_{\mathrm{e}}\right)=L\left(\theta_{\mathrm{i}}-\theta_{\mathrm{e}}\right)$

where $L$ - thermal coupling coefficient, $\left(\mathrm{W} /{ }^{\circ} \mathrm{C}\right)$.

Any layer added to the initial one introduces its own resistance, which is why the overall resistance of the multilayer wall depends not only on the thermal conductivity and thickness of each layer, but also on its orientation with respect to the heat flux [11]. As each construction element has finite dimensions and their ends are connected to other elements, thermal resistance is corrected, considering the more intense heat flux at joints, i.e. the thermal bridges. 
Moreover, the external temperature is different for different elements of the envelope, which is why the coupling coefficient is also corrected.

The significant thermal capacity of the soil, associated with the random variation of the main climatic parameters, determines in fact a non-stationary character of heat transfer that generates both-way heat fluxes. The coupling coefficient for the ground floor is influenced by the presence of underground water.

The energy needed for heating a building is determined from a thermal balance equation, as the difference between the heat flux lost by conduction and convection through the building's thermal envelope and by air permeability of the walls, and the heat intake from the sun and from internal sources. The lost heat flux is written as:

$\dot{Q}=H\left(\theta_{\mathrm{i}}-\theta_{\mathrm{e}}\right)$

where: $H$ - coefficient of total heat losses through the building's thermal envelope, $\left(\mathrm{W} \cdot{ }^{\circ} \mathrm{C}^{-1}\right)$.

The coefficient of total heat losses through the building's thermal envelope has two components:

$H=H_{\mathrm{T}}+H_{\mathrm{V}}$

where: $H_{\mathrm{T}}$ - coefficient of heat losses by conduction and convection, $\left(\mathrm{W} \cdot{ }^{\circ} \mathrm{C}^{-1}\right) ; H_{\mathrm{V}}-$ coefficient of heat losses due to air permeability of the envelope, $\left(\mathrm{W}^{\circ} \mathrm{C}^{-1}\right)$.

\subsection{Methodology}

The assessed house has three categories of energy consumption: for heating, for hot water preparation and for lightening. The house uses no regenerable energy sources. The heating system and the preparation of the hot water system use gas as a source of energy.

The study focuses on the heating energy consumption.

The ratio of the thermal envelope area over the heated volume is $1.18 \mathrm{~m}^{2} \mathrm{~m}^{-3}$, higher than the limit of $0.7 \mathrm{~m}^{2} \mathrm{~m}^{-3}$ requested for an efficient, compact house.

According to the geometry of the house and the thermal properties of the materials that the envelope components are made of, the house coefficient of heat losses by transmission is $H_{\mathrm{T}}=99.19 \mathrm{~W} \cdot{ }^{\circ} \mathrm{C}^{-1}$, calculated with the coupling coefficients shown in Tab. 1.

Table 1 Thermal coupling coefficient of the envelope

\begin{tabular}{|c|c|c|c|c|}
\hline \multicolumn{2}{|c|}{$\begin{array}{c}\text { Thermal } \\
\text { envelope element }\end{array}$} & $\begin{array}{l}\text { Area } \\
\left(\mathrm{m}^{2}\right)\end{array}$ & $\begin{array}{l}\text { Corrected thermal } \\
\text { resistance }\left({ }^{\circ} \mathrm{C} \cdot \mathrm{m}^{2} / \mathrm{W}\right)\end{array}$ & $\begin{array}{l}\text { Thermal coupling } \\
\text { coefficient }\left(\mathrm{W} /{ }^{\circ} \mathrm{C}\right)\end{array}$ \\
\hline \multicolumn{2}{|c|}{ Ground floor } & 126.16 & 2.04 & 29.80 \\
\hline \multicolumn{2}{|c|}{ Upper floor } & 126.16 & 2.51 & 24.17 \\
\hline \multirow{5}{*}{ Wall } & windows & 12.60 & 0.77 & 16.36 \\
\hline & $\mathrm{N}$ & 17.68 & 3.28 & 5.39 \\
\hline & $\mathrm{S}$ & 13.9 & 2.83 & 4.92 \\
\hline & $\mathrm{E}$ & 40.58 & 4.25 & 9.55 \\
\hline & $\mathrm{V}$ & 42.38 & 4.70 & 9.01 \\
\hline
\end{tabular}

Considering a medium class of air permeability, $H_{\mathrm{V}}=$ $63.74\left(\mathrm{~W} \cdot{ }^{\circ} \mathrm{C}^{-1}\right)$, the total coefficient is $H=162.93\left(\mathrm{~W} \cdot{ }^{\circ} \mathrm{C}^{-1}\right)$.

The equilibrium external temperature, the one at which there is no heat flux through the building's envelope [12], results in $\theta_{\text {ed }}=15.82{ }^{\circ} \mathrm{C}$. Consequently, a 226 days heating period is obtained, as shown in Fig. 4, where the average temperature in each month, $\theta_{\mathrm{es}}$, is represented against the equilibrium temperature, $\theta_{\mathrm{ed}}$.

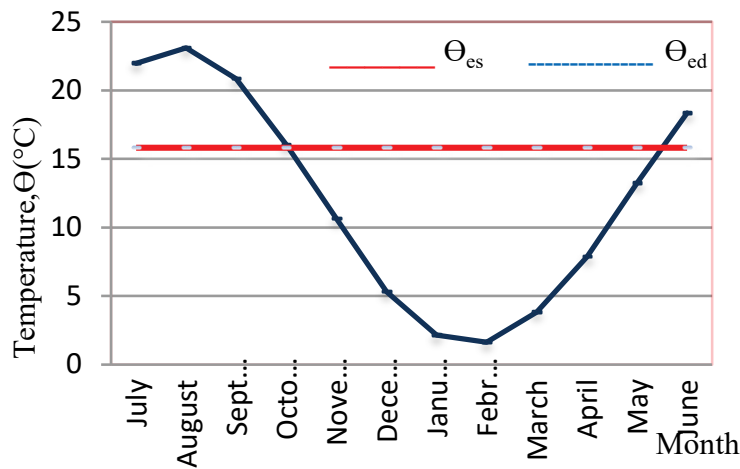

Figure 4 Heating period

The specific energy consumed for heating results in $q_{\mathrm{h}}=$ $71 \mathrm{~kW} \cdot \mathrm{h} \cdot \mathrm{m}^{-2} \cdot$ year $^{-1}$. Looking at the thermal resistances in Tab. 1, one may notice a smaller value for the ground floor, which results in a higher dissipated thermal flux.

Adding the energy consumption for hot water preparation and for lightening, the total specific energy consumed for the house rises to $q_{\mathrm{h}}=138 \mathrm{~kW} \cdot \mathrm{h} \cdot \mathrm{m}^{-2} \cdot$ year $^{-1}$. The corresponding primary energy is $E_{\mathrm{p}}=163 \mathrm{~kg} \cdot \mathrm{m}^{-2} \cdot$ year $^{-1}$ and the carbon dioxide footprint is $E_{\mathrm{CO} 2}=23 \mathrm{~kg} \cdot \mathrm{m}^{-2} \cdot$ year $^{-1}$.

The same assessment was performed for the reference house, associated to the real one. The reference house is a virtual one, with the same geometry as the real house, but with high thermal resistance of the envelope (the minimal required values are stipulated by regulations [12]) and appropriate operation of the heating systems that result in minimal possible energy consumption. For the reference house, the total specific energy decreases to $q_{\mathrm{t}}=104$ $\mathrm{kW} \cdot \mathrm{h} \cdot \mathrm{m}^{-2} \cdot \mathrm{year}^{-1}$, mainly due to the good thermal insulation of the ground floor.

Starting from this observation, a simple technical solution arises, which may improve the energy performance of the house: a cheap but efficient insulating layer on the ground floor. It significantly increased the corrected thermal resistance to $3.57^{\circ} \mathrm{C} \cdot \mathrm{m}^{2} \cdot \mathrm{W}^{-1}$. Even so, the thermal resistance of the floor is smaller than the recommended one, which is $4.5^{\circ} \mathrm{C} \cdot \mathrm{m}^{2} \cdot \mathrm{W}^{-1}$ for new houses.

The same energy performance assessment was performed for the real house, considering the additional insulation of the ground floor. This is the case the study focuses on as an improvement technical solution (referred to as solution in Tab. 2 and Tab. 3). The investigations continue with the determination of the additional investment cost to insulate the ground floor, the payback period of time and the price of the saved energy. These indicators are needed to decide whether the proposed technical solution is appropriate from an economic point of view. 
Subsequently, the same procedure was performed considering a similar version of the house, keeping the same heated volume, but with the two apartments placed one above the other. That means a vertical duplex, with half area of the ground floor, but the same heated area and the same heated volume. The house would become more compact, as the ratio of the thermal envelope area over the heated volume decreases to $0.9 \mathrm{~m}^{2} \mathrm{~m}^{-3}$.

\section{COMPARATIVE RESULTS REGARDING ENERGY PERFORMANCE}

The energy performance assessment of the original house (horizontal duplex) was performed, following the same methodology, for the real house, the reference associated one and the real house with a simple solution for an improved performance. The results regarding the main technical indicators are gathered in the Tab. 2 .

The first thing that draws attention when looking at the results in Tab. 2 is the big difference between the specific energy needed to heat the real house and the reference one. Despite the good thermal resistance of the walls and the upper floor, the weak thermal properties of the ground floor greatly influence the heat transmission coefficient. It is obvious that measures must be taken to decrease the heating energy consumption. The proposed solution, to add an insulation layer to the ground floor, seems to be appropriate since it decreases the heat transmission coefficient from 163 $\mathrm{W} \cdot{ }^{\circ} \mathrm{C}^{-1}$ to $145 \mathrm{~W} \cdot{ }^{\circ} \mathrm{C}^{-1}$. This solution results in the decreasing of the heating energy with about $17 \%$. The overall energy saving is about $10 \mathrm{~kW} \cdot \mathrm{h} \cdot \mathrm{m}^{-2} \cdot$ year $^{-1}$.

Table 2 Energy performance indicators. Horizontal duplex

\begin{tabular}{|c|l|c|c|c|c|}
\hline No & \multicolumn{1}{|c|}{ Indicator } & U.M. & Real house & Reference house & Solution \\
\hline 1 & Heat transmission coefficient & $\mathrm{W} /{ }^{\circ} \mathrm{C}$ & 163 & 118 & 145 \\
\hline 2 & Equilibrium external temperature & ${ }^{\circ} \mathrm{C}$ & 15.82 & 14.23 \\
\hline 3 & Average external temperature (cold season) & ${ }^{\circ} \mathrm{C}$ & 6.82 & 6.07 & 15.30 \\
\hline 4 & Heating period & day & 226 & 206 \\
\hline 5 & Specific energy consumption for heating & $\mathrm{kWh} / \mathrm{m}^{2}$ year & 65 & 39 & 219 \\
\hline 6 & Total specific energy consumption & $\mathrm{kWh} / \mathrm{m}^{2}$ year & 138 & 104 & 54 \\
\hline 7 & Specific primary energy for heating & $\mathrm{kg} / \mathrm{m}^{2}$ year & 71 & 43 & 128 \\
\hline 8 & Total specific primary energy & $\mathrm{kg} / \mathrm{m}^{2}$ year & 163 & 135 & 159 \\
\hline 9 & Specific carbon dioxide footprint & $\mathrm{kg} / \mathrm{m}^{2}$ year & 23 & 20 & 21 \\
\hline
\end{tabular}

Table 3 Energy performance indicators. Vertical duplex

\begin{tabular}{|c|c|c|c|c|c|}
\hline No & Indicator & U.M. & Real house & Reference house & Solution \\
\hline 1 & Heat transmission coefficient & $\mathrm{W} /{ }^{\circ} \mathrm{C}$ & 156 & 116 & 136 \\
\hline 2 & Equilibrium external temperature & ${ }^{\circ} \mathrm{C}$ & 15.63 & 14.13 & 14.98 \\
\hline 3 & Average external temperature (cold season) & ${ }^{\circ} \mathrm{C}$ & 6,82 & 6.07 & 6.59 \\
\hline 4 & Heating period & day & 224 & 206 & 216 \\
\hline 5 & Specific energy consumption for heating & $\mathrm{kWh} / \mathrm{m}^{2}$ year & 61 & 38 & 49 \\
\hline 6 & Total specific energy consumption & $\mathrm{kWh} / \mathrm{m}^{2}$ year & 135 & 102 & 123 \\
\hline 7 & Specific primary energy for heating & $\mathrm{kg} / \mathrm{m}^{2}$ year & 67 & 41 & 54 \\
\hline 8 & Total specific primary energy & $\mathrm{kg} / \mathrm{m}^{2}$ year & 159 & 133 & 146 \\
\hline 9 & Specific carbon dioxide footprint & $\mathrm{kg} / \mathrm{m}^{2}$ year & 22 & 20 & 20 \\
\hline
\end{tabular}

Speaking in terms of power per unit of area, the heating flux needed by the improved house is $30 \%$ of that mentioned by [5], and moreover, the reference house needs a much smaller amount to be heated.

The carbon dioxide footprint of the real house classifies it in the pollution class $\mathrm{A}+$; therefore, the original house proves to be an environment friendly one.

However, the real house has a higher primary energy consumption that an nZEB one. It is imposed that an nZEB residence should have the primary energy consumption of $E_{\mathrm{p} \mathrm{nZEB}}=98 \mathrm{~kg} \cdot \mathrm{m}^{-2} \cdot \mathrm{year}^{-1}$. Therefore, it is rational to look for energy improvement solutions.

The energy efficiency assessment shows that the performance of the original house may be improved by insulating the ground floor. It is a simple and relatively cheap solution. Besides, other simple technical solutions may be taken into consideration, but their impact weighs less. Complex technical solutions may also be considered, but they are too expensive.
Referring to the proposed solution, the price of the saved energy is 0.05 Euro $\mathrm{kW} \cdot \mathrm{h}^{-1}$. The amount of the saved energy results in a payback period of about 7.4 years.

Taking into consideration the vertical duplex version of the house, a further improvement of the energy performance may be noticed. The same indicators as for the horizontal duplex were written in Tab. 3 .

Comparing the data in Tab. 2 to the corresponding ones in Tab. 3, one may notice that the heating period during the cold season decreased by 2 days for the vertical duplex with no additional insulating layer (real house), and by 3 days for the improvement solution. The energy consumption for heating decreased by $6 \%$ for the real house and by $9 \%$ for the improvement solution.

\section{CONCLUSIONS}

Timber structured houses are a recommended choice for rapid building with a low budget. They are sustainable constructions and offer a comfortable and healthy ambiance for their inhabitants. 
A house built for a low-income family must be conceived with aiming not only at a low investment cost, but also at the energy efficiency of the building.

The methodology used in this study relies on the heat balance in the thermal envelope of a wooden-made building, placed in a dry temperate climate region, with respect only to the heating energy. Further investigation regarding the cooling energy has to be performed as wooden houses with low thermal capacity may overheat during the summer.

The energy efficiency of the analysed wooden house could be improved by increasing the thermal resistance of the ground floor, the element that covers $30 \%$ of the envelope area. By increasing it with $70 \%$, the heating energy decreases by $17 \%$.

By insulating the concrete ground floor, the primary heating energy consumption decreases to $E_{\mathrm{p}}=54$ $\mathrm{kg} \cdot \mathrm{m}^{-2} \cdot$ year $^{-1}$. Taking into account that the total primary energy requested for a nZEB is $E_{\mathrm{p}}=98 \mathrm{~kg} \cdot \mathrm{m}^{-2} \cdot \mathrm{year}^{-1}$, it results in the fact that the analysed house may be turned into a nZEB acting on two directions: by diminishing the energy for hot water preparation and by introducing regenerable energy sources. The emplacement of the houses and the appropriate insulation of the region make the photovoltaic panels very suitable for this purpose.

The vertical duplex version, with a smaller ratio of the thermal envelope area over the heated volume could have been a better choice for the wooden house. The reference house in the vertical version needs $3 \%$ less of heating energy than the horizontal one, for the same heated volume and the same heated area. Referring to the improved solution, the heating energy saving is up to $9 \%$ in the case of the vertical version.

\section{Acknowledgments}

The author wishes to acknowledge the assistance of the jurist Mihaela Popa, representative of the Habitat for Humanity Cumpăna.

\section{Notice}

The paper will be presented at PBE2020 - International Scientific Conference "People, Buildings and Environment $2020 "$ " The $14^{\text {th }}$ conference will be held in the Rožnov pod Radhoštěm city, the Czech Republic, from 7 to 9 October 2020. The paper will not be published anywhere else.

\section{REFERENCES}

[1] Feifer, L., Imperadori, M., Salvalai, G., Brambilla, A. \& Brunone, F. (2018). Active house: smart nearly zero buildings. PoliMI SpringerBriefs. https://doi.org/10.1007/978-3-319-90814-4_1

[2] Building projects for houses type Habitat, in Cumpăna http://www.primaria-cumpana.ro/proiecte.html.

[3] Steinberg, E., Selle, R. \& Faust, T. (2003). Connectors for timber-lightweight concrete composite structures. J. Struct. Eng. 129, 1538-1545.

https://doi.org/10.1061/(ASCE)0733-9445(2003)129:11(1538)
[4] Němeček, M. \& Kalousek, M. (2015). Influence of thermal storage mass on summer thermal stability in a passive wooden house in the Czech Republic. Energy and Buildings, 107, 6875. https://doi.org/10.1016/j.enbuild.2015.07.068

[5] Päätalo, J. (2016). Log house - a blueprint for future energy efficient buildings? Energy Procedia 96, 345-350. https://doi.org/10.1016/j.egypro.2016.09.157

[6] Kawasaki, T. \& Kawai, S. (2006). Thermal insulation properties of wood-based sandwich panel for use as structural insulated walls and floors. $J$ Wood Sci, 52, 75-83. https://doi.org/10.1007/s10086-005-0720-0

[7] Czajkowski, L., Olek, W., Weres, J., \& Guzend, R. (2016). Thermal properties of wood-based panels: thermal conductivity identification with inverse modelling. European Journal of Wood and Wood Products, 74, 577-584. https://doi.org/10.1007/s00107-016-1021-6

[8] Zehn, M. \& Zhang, B. P. (2018). Energy Performance of a Light Wood-Timber Structured House in the Severely Cold Region of China. Sustainability, 10(15), 1501, 1-18. https://doi.org/10.3390/su10051501

[9] Börjesson, P. \& Gustavsson, (2000). Greenhouse gas balances in building construction: wood versus concrete from life-cycle and forest land-use perspectives, Energy Policy, 28, 9, 575588. https://doi.org/10.1016/S0301-4215(00)00049-5

[10] Lenzena, M. \& Treloarb, L. (2002). Embodied energy in buildings: wood versus concrete-reply to Börjesson and Gustavsson. Energy Policy, 30(3), 249-255. https://doi.org/10.1016/S0301-4215(01)00142-2

[11] Constantin, A. (2001), Technical thermodynamics, Ovidius University Press, Constanta

[12] Calculation methodology for the energy performance of buildings, Mc 001/2006, (2017), Matrixrom, Bucharest.

\section{Author's contacts:}

Anca Constantin, $\mathrm{PhD}$

Faculty of Civil Engineering,

Ovidius University,

22b Unirii Str., 900524 Constanta, Romania

Tel: +40742030709

E-mail: aconstantina@univ-ovidius.ro 